\title{
Montia fontana L. (Portulacaceae), an interesting wild vegetable traditionally consumed in the Iberian Peninsula
}

\author{
J. Tardío $\cdot$ M. Molina $\cdot$ L. Aceituno-Mata $\cdot$ M. Pardo-de-Santayana • \\ R. Morales $\cdot$ V. Fernández-Ruiz $\cdot$ P. Morales $\cdot$ \\ P. García • M. Cámara • M. C. Sánchez-Mata
}

Received: 15 April 2011/Accepted: 16 August 2011/Published online: 8 September 2011

(C) Springer Science+Business Media B.V. 2011

\begin{abstract}
Montia fontana L. is an aquatic plant traditionally consumed in the Centre and West of the Iberian Peninsula, where it is one of the most highly valued wild vegetables. The aim of this work was to evaluate both the natural yield and nutritional value of this scarcely known plant. Two wild populations, from two different sites of Central Spain, were sampled during three consecutive years. Plant production was estimated by two parameters: production per unit of surface and plant percentage cover in the selected site. Nutritional analyses included proximate composition and total energy, mineral macro and
\end{abstract}

J. Tardío $(\bowtie) \cdot$ M. Molina $\cdot$ L. Aceituno-Mata Instituto Madrileño de Investigación y Desarrollo Rural, Agrario y Alimentario (IMIDRA), Finca El Encín. Apdo 127, 28800 Alcalá de Henares, Madrid, Spain e-mail: javier.tardio@madrid.org

M. Molina

e-mail: m.molina.simon@madrid.org

L. Aceituno-Mata

e-mail: aceitunomata@yahoo.es

M. Pardo-de-Santayana

Departamento de Biología (Botánica), Universidad Autónoma de Madrid (UAM) c/Darwin 2, Campus de Cantoblanco, 28049 Madrid, Spain e-mail: manuel.pardo@uam.es

R. Morales

Real Jardín Botánico de Madrid, CSIC, Plaza de Murillo 2, 28014 Madrid, Spain e-mail: morales@rjb.csic.es microelements, vitamin $\mathrm{C}$, and organic acids. Mean yield at the growing areas was $2.64 \mathrm{~kg} / \mathrm{m}^{2}$, though significant differences among sites and years were found. There was a positive correlation between production and accumulated rainfall from the beginning of the year till the collecting dates. The percentage cover of the species in the potential growing area was $8.25 \%$, without significant differences among sites and years. Therefore, the wild populations of the species can reach a total mean production of $2,138 \mathrm{~kg} / \mathrm{ha}$ in this Spanish region. This is the first report of a global nutrient composition for Montia fontana. After

\footnotetext{
V. Fernández-Ruiz · P. García · M. Cámara ·

M. C. Sánchez-Mata

Dpto. Nutrición y Bromatología II, Facultad de Farmacia, Universidad Complutense de Madrid (UCM),

Plaza Ramón y Cajal s/n, 28040 Madrid, Spain

e-mail: vfernand@farm.ucm.es

P. García

e-mail: patriciagarciaherrera@estumail.es

M. Cámara

e-mail: mcamara@farm.ucm.es

M. C. Sánchez-Mata

e-mail: cortesm@farm.ucm.es

P. Morales

Dpto. de Ciencias de la Salud, Universidad Internacional

Valenciana (VIU), c/José Pradas Gallen s/n,

12000 Castellón de la Plana, Spain

e-mail: patricia.morales@campusviu.es
} 

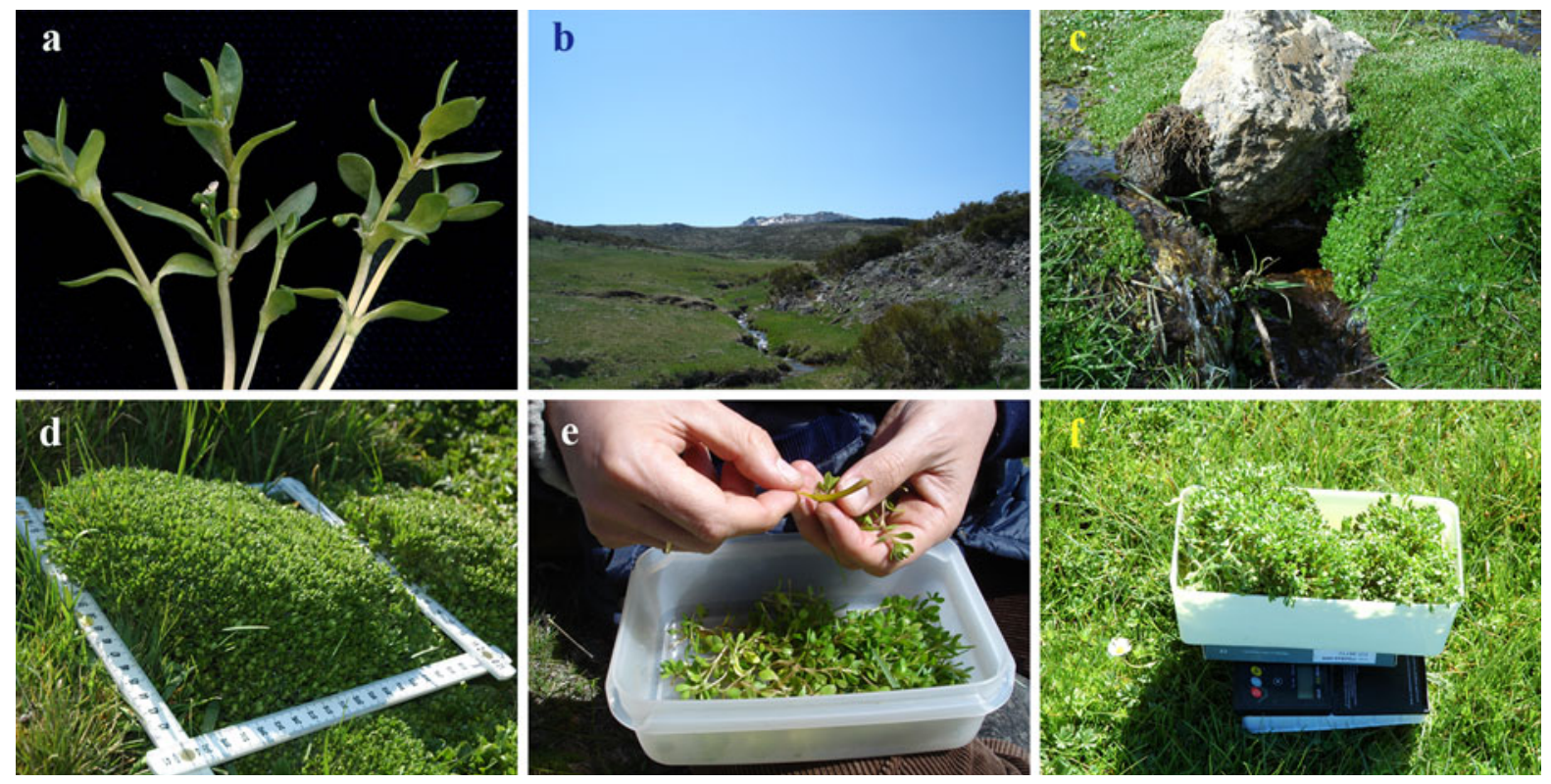

Fig. 1 Montia fontana: a detail of the plant at the flowering time; $\mathbf{b}$ and $\mathbf{c}$ habitat in Site 2. Estimation of yield per unit of surface: d sampling a square of $20 \times 20 \mathrm{~cm}$, e and f cleaning and weighing the samples

moisture, the major constituent was fibre (4.44\%), much higher than many cultivated vegetables. Also appreciable amounts of vitamin C (34 $\mathrm{mg} / 100 \mathrm{~g})$ and Mn (1.07 mg/100 g) were found. Due to its high lipid content $(1.94 \%)$ this wild vegetable could be regarded as one of the richest source of omega-3 fatty acids among the leafy vegetables. This species can be considered an interesting wild resource for being included in the diet. Further research is needed for addressing its potential for being cultivated under different culture systems and for selecting accessions with lower oxalate content.

Keywords Montia fontana - Natural production . Nutritional composition · Portugal · Spain · Wild vegetables

\section{Introduction}

Montia fontana L., known in English as blinks or water-blinks, belongs to the family Portulacaceae. It grows in clumps in damp places, frequently in water, in springs, streams, wet places among rocks and moist pastures, especially on non-calcareous soils (see Fig. 1). It can be found in many temperate regions throughout the world (PFAF 2011) including some European areas, but it is rare in the East and South Europe (Walters 1964).

\section{Nomenclature}

\section{Montia fontana L., Sp. P1.: 87 (1753)}

Following Paiva et al. (1986) and Paiva and Villanueva (1990), three subspecies grow in the Iberian Peninsula: subsp. fontana, subsp. chondrosperma (Fenzl) Walters, and subsp. amporitana Sennen. The fourth subspecies recognized by Walters (1964), the subsp. variabilis Walters, was included in subsp. amporitana by the former authors.

\section{Common names}

English: blinks, water-blinks. Spanish: corujas, borujas, morujas, pamplinas and regajos. Portuguese: morujas, merujas or merujes.

\section{Taxonomic characters}

Annual or perennial, glabrous and fleshy herb, with thin and branching stems up to $50 \mathrm{~cm}$ or more when 
it grows in water and shorter when appears in land. Small, opposite and spathulate leaves (3-20 mm). Inconspicuous flowers of $2 \mathrm{~mm}$ in terminal cymes, with 3 sepals, 5 white petals, 3 stamens and 3 ovules. Fruit in a globose capsule dehiscent by 3 valves and usually with 3 black, reticulated and reniform seeds.

\section{Edible use}

The young and tender stems and leaves of this plant are traditionally consumed in the regions of the Iberian Peninsula where it grows. There are many modern ethnobotanical references from Western and Central Spain. Most of them were registered in a previous review of wild edible plants in Spain (Tardío et al. 2006), but other later works have also included the use of this wild vegetable (ADISAC 2006; Criado et al. 2008; Díaz-Fernández et al. 2008; González et al. 2010; Velasco et al. 2010). Ethnobotanical studies in the North of Portugal have also recorded the same use for the species (Alves Ribeiro et al. 2000; Pardo de Santayana et al. 2007). This is one of the most valued wild vegetables in these regions, especially in the Spanish province of Salamanca, where it is mentioned in lots of references (e.g. González et al. 2010; Velasco et al. 2010). A recent ethnobotanical study in the North of Madrid (Aceituno-Mata 2010) found that Montia fontana was one of the most important wild vegetables and still consumed by $64 \%$ of the informants that cited its use. This percentage was higher than that of other salad wild vegetables, like Rorippa nasturtiumaquaticum (L.) Hayek (58\%) or Rumex papillaris Boiss. et Reut. (39\%). Despite being mentioned in some European sources (Couplan 1989; PFAF 2011), we only have found one clear ethnobotanical reference about its traditional use in Central Europe (Jage 1979). Following this author, at the end of the nineteenth century, water-blinks were sold in markets as a vegetable, especially in winter. In fact, several German folk names registered in Central Europe reflects its use as a salad vegetable: Flachssalat (Vosges), Winzerlsalat (Lower Bavaria), Schnippchensalat (Saxony).

Water-blinks are always eaten raw in salads after being meticulously cleaned (e.g. Tardío et al. 2005, 2006). These salads are prepared dressing the plants with salt, vinegar and olive oil. Other ingredients, such us garlic, olives, preserved tomatoes, dry pepper, paprika, hard-boiled eggs and tuna are sometimes added. It is consumed even nowadays, being still possible to find it in some greengrocers and even in some restaurants.

The plant must be harvested before the flowering period, prior to its nice flavour turn bitter (DíazFernández et al. 2008; PFAF 2011). Several proverbs point out this fact, stating that when you can hear the call of the Cuckoo, the water-blinks are no longer suitable to eat, because they will be surely flowered. The plants have to achieve enough size to be collected. If scarcely developed, they carry a lot of mud when they are cut and then it takes a long time to clean them (Tardío et al. 2002). Therefore, in Spain they are collected from winter, in the milder areas, such as many places of Extremadura (Blanco and Cuadrado 2000), to spring, in the more continental areas, such as those of Madrid and Castilla-León (e.g. Díaz-Fernández et al. 2008). Some informants report that plants collected in highlands are better than those from the lowlands. They are smaller but tastier (Blanco 1998).

Regarding its ethnopharmacological use in the Iberian Peninsula, we only could find one reference, in Montesinho, Portugal (Carvalho 2010). A very hot poultice of the plant fried in olive oil is applied over the bladder as a diuretic to treat difficulty urinating and pain caused by cystitis. Other external medicinal use has also been described in Scotland (Allen and Hatfield 2004). The previously heated plant was placed on the affected area to treat suppurating sores and rheumatism.

The contribution of wild vegetables to the diet is also well documented, especially for satisfying the macro- and micronutrient needs of groups at risk, such as children, pregnant and/or lactating women, or the elderly (e.g. Flyman and Afolayan 2006; Grivetti and Ogle 2000; Ogle 2001). Green leafy vegetables are, in general, good sources of fibre, vitamins and minerals, as key compounds for health promotion, like recent epidemiological studies suggest (Lasheras et al. 2000). The need for increasing the fibre consumption in Western populations for its beneficial effects, such as the regulation of the intestinal function and the prevention of colon cancer, has been recently remarked (EFSA 2010). Related to micronutrients, the nutritional importance of vitamin $\mathrm{C}$ as an essential water-soluble vitamin, as well as for its antioxidant properties is well established (Phillips et al. 2010). Also trace elements such as $\mathrm{Cu}, \mathrm{Mn}$ and 
$\mathrm{Zn}$ (as cofactors of antioxidant enzymes), have an important role in the prevention of chronic diseases and also in improving the immune function. Other elements, such as $\mathrm{Mn}, \mathrm{Fe}, \mathrm{Cu}$ and $\mathrm{Zn}$ play a key role in the protection mechanisms by scavenging free radicals (McDermott 2000). Organic acids are primary metabolites involved in several biochemical pathways and play an important role as photosynthetic intermediates. The profile of organic acids varies depending on the species, age of the plant and the tissue type (López-Bucio et al. 2000). They are the responsible of the acid-sour flavour of the plant, especially due to citric and malic acids, but also to ascorbic acid (Oliveira et al. 2008). Oxalic acid is usually considered an anti-nutritional factor for its relation with the absorption of calcium.

To the authors' knowledge, there is a lack of information about the nutritional composition of Montia fontana. Schelstraete and Kennedy (1980) analysed the nutritional value of the close-related species Claytonia perfoliata Donn ex Wild. [synonym, Montia perfoliata (Donn ex Willd.) Howell]. This American species is consumed as a vegetable as well, eaten fresh or boiled, being known as miner's lettuce or winter purslane (Moerman 1998; Munro and Small 1997). It is also naturalized in Central and Western Europe (Paiva and Villanueva 1990; Walters 1964) and even occasionally cultivated in the United States, South America, W and S Europe and in tropical Africa as a vegetable for raw consumption and as a pot herb (Hammer 2001).

Another aspect that has not been sufficiently studied is the quantification of wild plant resources availability, especially for wild vegetables. Except for some commercial wild fruits (e.g. Kerns et al. 2004; Miinaa et al. 2010; Molina et al. 2011; Murray et al. 2005), there are only a few works on wild plants yield in terms of edible biomass (e.g. Youngblood 2004). To the authors' knowledge, though its interest as a potential crop plant has been recently mentioned (Sánchez-Monge 2001), no studies have been carried out on the edible production of Montia fontana.

Due to the interest of this scarcely known plant, the aim of this study was to evaluate both its natural yield and nutritional value in two sites of Central Spain. On one hand, the estimation of the natural production of this plant can be very useful in order to assess the availability and sustainability of this resource. On the other hand, the knowledge of its nutritional composition may contribute to a better valorisation of this traditional resource and can aid to know its influence in the past diets and also its interest for the future.

\section{Methodology}

Study sites and harvesting dates

Two wild populations of Montia fontana subsp. amporitana were selected to carry out this survey. Water-blinks grew along the stream-sides and the associated flooding areas of two localities of Central Spain (Table 1). As can be seen in the table, Site 1 is dryer and hotter than Site 2 that is located almost $700 \mathrm{~m}$ higher in the highlands of Guadarrama mountain range. The area of study of Site 1 included a stream section of $950 \mathrm{~m}$ length and 10-15 m width in the widest places, whereas at Site 2 comprised $1,120 \mathrm{~m}$ length and $1 \mathrm{~m}$ width with $5 \mathrm{~m}$ in the widest sections.

The sampling was carried out choosing the best moment of harvesting, i.e. when the plants have reached the maximum development before flowering. As shown in Table 1, water-blinks were harvested at the end of March at Site 1. However, the plants from Site 2, almost $700 \mathrm{~m}$ higher and therefore colder, were developed and collected about a month later, at the end of April.

Natural production estimations

Water-blinks yield was quantified in two phases. Firstly, the production per unit of surface was evaluated and, in a second stage, the abundance of the plant in the selected site was estimated as percentage cover.

The yield of plant per unit of surface was evaluated during two or three consecutive years in the two selected sites (see Table 1). Since we wanted to measure the yield of the plant, we selected only the areas where the plant was present. The sample unit was a quadrat, i.e. a square frame, of $20 \times 20 \mathrm{~cm}$ $\left(0.04 \mathrm{~m}^{2}\right)$. The fresh usable part from 20 quadrates randomly placed into the clumps formed by the species was harvested with scissors and weighed in a field scale (see Fig. 1). Before weighing, a meticulous cleaning of the plant material was performed to separate other 
Table 1 Location, climatic features and harvesting dates of the two selected sites

\begin{tabular}{lll}
\hline & Site 1 & Site 2 \\
\hline Area & Arroyo grande & Puerto de la Morcuera \\
Municipality & Ituero y Lama & Rascafría \\
Province & Segovia & Madrid \\
Geographical coordinates & $40^{\circ} 49^{\prime} \mathrm{N} ; 4^{\circ} 23^{\prime} \mathrm{W}$ & $40^{\circ} 50^{\prime} \mathrm{N} ; 3^{\circ} 49^{\prime} \mathrm{W}$ \\
Altitude $(\mathrm{m})$ & 1,020 & 1,700 \\
Mean annual rainfall $(\mathrm{mm})$ & 480 & 1,350 \\
Mean annual temperature $\left({ }^{\circ} \mathrm{C}\right)$ & 10.8 & 6.3 \\
Harvesting dates & $16 / 04 / 2007,31 / 03 / 2008,25 / 03 / 2009$ & $27 / 4 / 2008,29 / 4 / 2009$ \\
\hline
\end{tabular}

plant species that often grow in the same place, such as Stellaria alsine Grimm and Ranunculus hederaceus L. A representative fraction of these samples was selected for the nutritional analysis.

Plant abundance, expressed as the percentage cover of the species at the two study sites was evaluated through more than 20 transects of $10 \times 1 \mathrm{~m}$ randomly located along the gathering places. According to total surface sampled in each location, we performed 20 transects at Site 1 and 30 at Site 2. The number of $20 \times 20 \mathrm{~cm}$ quadrates occupied by the plant was counted in each transect and subsequently the percent covered area was calculated. The sampling was carried out in 2009 at both locations and also in 2008 at Site 2 to assess between year variations.

\section{Nutritional analysis}

As mentioned before, an aliquot part of the samples used for yield estimations was also evaluated for nutritional composition. Therefore, along the three years of study, five different samples were analysed, three from Site 1 (2007, 2008 and 2009) and two from Site 2 (2008 and 2009). At least $500 \mathrm{~g}$ of edible portion (young and tender stems with leaves) were chosen for each sample, packed in plastic bags, and transported to the laboratories in a cold system within the day. All the plants selected presented a healthy external appearance.

A part of the fresh samples was immediately homogenized in a laboratory blender. Aliquots were taken to analyze moisture, organic acids and total vitamin $\mathrm{C}$, both in the form of ascorbic acid (AA) and dehydroascorbic acid (DHA). The other part of the samples were freeze-dried and kept at $-20^{\circ} \mathrm{C}$, in a dark, dry ambient. Analysis performed on dry samples were: total available carbohydrates (TAC), total dietary fibre, total proteins, fat content, ash and mineral elements ( $\mathrm{Na}, \mathrm{K}, \mathrm{Ca}, \mathrm{Mg}, \mathrm{Fe}, \mathrm{Cu}, \mathrm{Mn}, \mathrm{Zn}$ ). Triplicate sub-samples were taken for all the analytical procedures.

Moisture content was determined by desiccation to constant weight at $100 \pm 2^{\circ} \mathrm{C}$ (AOAC 2006). Total available carbohydrate (TAC) determination was carried out by a colorimetric method using anthrone reagent after hydrolysis with $\mathrm{HClO}_{4}$, as described by Osborne and Voogt (1986). Absorbance was measured at $630 \mathrm{~nm}$ on a UV/Vis Spectrometer EZ210 (Perkin Elmer, Waltham, MA, USA) equipped with Lambda software PESSW version 1.2. The absorbance of the sample solution was compared to a $10-100 \mathrm{mg} / \mathrm{ml}$ concentration range standard glucose calibration curve.

Total dietary fibre was determined according to AOAC non enzymatic-gravimetric method 985.29 for total fibre (AOAC 2006). Total protein was determined from the nitrogen content obtained by the Kjeldahl method after digestion in sulfuric acid. Total nitrogen content was converted to protein content by using the conversion factor 6.25 (AOAC 2006). Fat content was determined gravimetrically after a continuous extraction process with ethyl-ether at $120^{\circ} \mathrm{C}$ for $6 \mathrm{~h}$ using a Soxtec System HT 1043 (Tecator).

Total mineral content (ashes) was determined gravimetrically by incineration in a high pressure microwave oven (Muffle Furnace mls1200) for $24 \mathrm{~h}$ at $550^{\circ} \mathrm{C}$, and gravimetrical quantification of the ashes obtained (method 930.05, AOAC 2006). The residue of incineration was extracted with $\mathrm{HCl}(50 \% \mathrm{v} / \mathrm{v})$ and $\mathrm{HNO}_{3}(50 \% \mathrm{v} / \mathrm{v})$ and made up to an appropriate volume with distilled water, where $\mathrm{Fe}, \mathrm{Cu}, \mathrm{Mn}$ and $\mathrm{Zn}$ were directly measured. An additional 1/10 (v/v) dilution was performed in $\mathrm{LaCl}_{2}(1.8 \%)$ for $\mathrm{Ca}$ and $\mathrm{Mg}$ 
determination, and $\mathrm{CsCl}_{2}(0.2 \%)$ for $\mathrm{Na}$ and $\mathrm{K}$ analysis. All measurements were performed in atomic absorption spectroscopy (AAS) in an Analyst 200 Perkin Elmer equipment.

Ascorbic acid (AA) and organic acids were quantified by High-Performance Liquid Chromatography (HPLC) after extraction with $4.5 \% \mathrm{~m}$-phosphoric acid (Sánchez-Mata et al. 2011). An aliquot of the extracts were also subjected to reduction with L-cysteine at a $\mathrm{pH}$ of 7, to transform the DHA in AA and analyse the total vitamin $\mathrm{C}$ content. The analytical equipment used was a liquid chromatographer (Micron Analítica, Madrid, Spain) equipped with an isocratic pump (model PU-II), an AS-1555 automatic injector (Jasco, Japan), a Sphereclone ODS (2) $250 \times 4.60,5 \mu \mathrm{m}$ Phenomenex column, a UVvisible detector (Thermo Separation Specta Series UV100); and software Biocrom 2000 version 3.0. The mobile phase was $1.8 \mathrm{mM} \mathrm{H}_{2} \mathrm{SO}_{4}(\mathrm{pH}=2.6)$. For AA analysis a flow-rate of $0.9 \mathrm{ml} / \mathrm{min}$ and UV detection at $245 \mathrm{~nm}$ was used, while conditions for organic acids were $215 \mathrm{~nm}$ UV detection and $0.4 \mathrm{ml} /$ min flow rate. Linear calibration curves were performed for quantification purposes with AA and other organic acids standards (oxalic, malic and citric acids) in $m$-phosphoric acid.

\section{Statistics}

Mean value \pm standard error (SE) is given for all the measured parameters. Between year and between site differences in production data were statistically analysed with the non-parametric MannWhitney U test. The nutritional analyses were carried out by triplicate. The mean differences among sites and years in nutritional parameters were analysed by ANOVA, followed by Duncan's multiple range test. All the procedures were tested with $\alpha=0.05$.

\section{Results and discussion}

Natural production estimations

Table 2 shows a summary of the yield parameters measured for estimating the natural production of Montia fontana at the two sites along the different seasons.
As can be seen in Table 2A, the mean yield per sampled quadrat fluctuated between $1.52 \pm 0.12 \mathrm{~kg} / \mathrm{m}^{2}$ (60.7 $\pm 4.7 \mathrm{~g}$ /quadrat) at Site 1 in 2008 and $3.91 \pm$ $0.29 \mathrm{~kg} / \mathrm{m}^{2}(156.2 \pm 11.5 \mathrm{~g} /$ quadrat $)$ at the Site 2 in 2009. Significant differences among sites and years were detected. The lowest production was found at both sites in the year 2008, coinciding with the driest spring of the study period (see Fig. 2). Production of Site 2 was significantly higher than that of Site 1 in the two common sampled years (2008 and 2009), though the highest production value at Site 1 was found in 2007. Total mean value was $2.64 \pm 0.13 \mathrm{~kg} / \mathrm{m}^{2}(105.6 \pm$ 5.1 g/quadrat).

Regarding the abundance of water-blinks in the surveyed areas, Table 2B shows the percentage cover of the species in the potential growing sites. As previously mentioned, abundance studies were carried out only at Site 2 in 2008 and at both sites in 2009. As can be seen in the table, the percentage cover was $8.34 \%$ at Site 1 and $8.21 \%$ at Site 2 without significant differences among sites and years (total mean: $8.25 \%$ ).

Taking into account the mean yield per quadrat and the percentage cover of the species, we calculated the production of Montia fontana in the total area surveyed (Table 2C). Since significant differences were not found in the percentage of area covered by the species, total production in 2008 at Site 1 has been estimated with plant abundance data of 2009. As expected by the values of yield per quadrat, the production of Site 2 has been significantly higher than that of Site 1 in the two common sampled years. Overall, a total mean production of $2,138 \pm 95 \mathrm{~kg} / \mathrm{ha}$ $\left(0.21 \pm 0.01 \mathrm{~kg} / \mathrm{m}^{2}\right)$ has been estimated for the species in this Spanish region. These data can be of interest for planning the sustainable harvest of waterblinks in protected areas.

Trying to explain the yield differences between sites and years of the study, the relationship among production and different meteorological data has been analysed. Meteorological conditions, particularly accumulated rainfall, seem to have positively influenced the production per quadrat, the yield parameter that better reflects between-years variance. Although with only 5 cases, a high, positive and significant correlation between the two parameters was detected (Spearman's coefficient: $0.9, P<0.05$ ). Figure 2 shows the accumulated rainfall from the beginning of the year till the collecting dates and 
Table 2 Yield parameters measured for Montia fontana in the two sites during the three years of study (mean \pm SE)

\begin{tabular}{llllll}
\hline & Location & 2007 & 2008 & 2009 & Total \\
\hline A. Production per quadrat $\left(\mathrm{kg} / \mathrm{m}^{2}\right)$ & Site 1 & $2.83 \pm 0.12 \mathrm{a}$ & $1.52 \pm 0.12 \mathrm{bA}$ & $1.98 \pm 0.16 \mathrm{cA}$ & $2.14 \pm 0.13 \mathrm{~A}$ \\
& Site 2 & N/A & $2.65 \pm 0.28 \mathrm{aB}$ & $3.91 \pm 0.29 \mathrm{bB}$ & $3.35 \pm 0.22 \mathrm{~B}$ \\
& Total mean & $2.83 \pm 0.12 \mathrm{a}$ & $2.09 \pm 0.18 \mathrm{~b}$ & $3.05 \pm 0.22 \mathrm{a}$ & $2.64 \pm 0.13$ \\
\hline B. Plant coverage $(\%$ of area) & Site 1 & N/A & N/A & $8.34 \pm 2.05 \mathrm{~A}$ & $8.34 \pm 2.05 \mathrm{~A}$ \\
& Site 2 & N/A & $9.32 \pm 2.89 \mathrm{a}$ & $7.11 \pm 1.27 \mathrm{aA}$ & $8.21 \pm 1.57 \mathrm{~A}$ \\
& Total mean & N/A & $9.32 \pm 2.89 \mathrm{a}$ & $7.60 \pm 1.11 \mathrm{a}$ & $8.25 \pm 1.28$ \\
\hline C. Production per area of habitat $(\mathrm{kg} / \mathrm{ha})$ & Site 1 & $2,362 \pm 96^{*} \mathrm{a}$ & $1,265 \pm 97 * \mathrm{bA}$ & $1,653 \pm 131 \mathrm{cA}$ & $1,760 \pm 86 \mathrm{~A}$ \\
& Site 2 & N/A & $2,474 \pm 265 \mathrm{aB}$ & $2,775 \pm 203 \mathrm{aB}$ & $2,641 \pm 154 \mathrm{~B}$ \\
& Total mean & $2,362 \pm 96^{*} \mathrm{a}$ & $1,870 \pm 170 \mathrm{~b}$ & $2,276 \pm 151 \mathrm{a}$ & $2,138 \pm 95$ \\
\hline
\end{tabular}

For each parameter, different letters mean significant differences $(P<0.05$; capital letter compare means in a column, regular letters in a row)

N/A not available

* Production of 2007 and 2008 at Site 1 has been estimated with plant coverage data from 2009
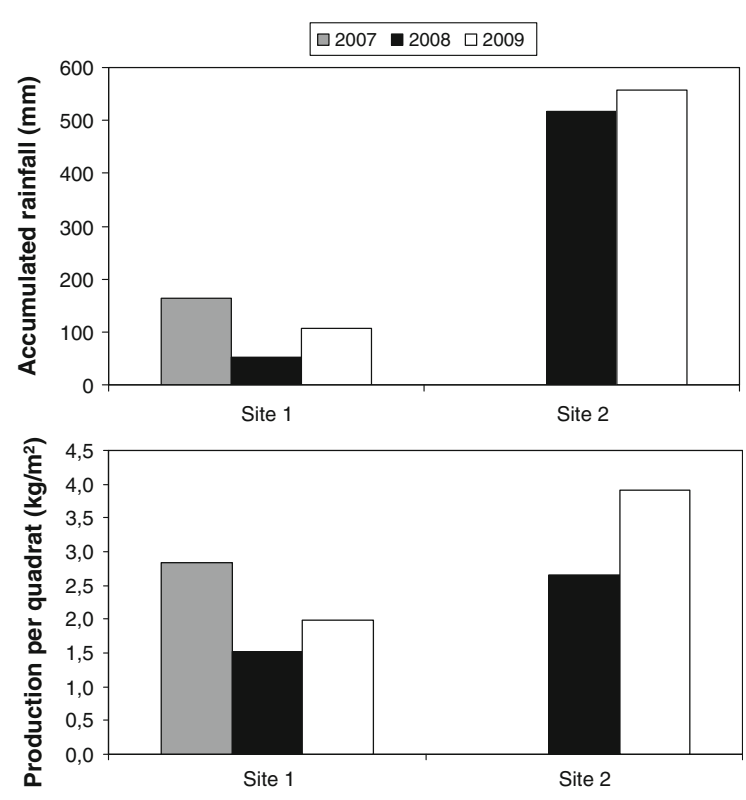

Fig. 2 Accumulated rainfall (mm) from January till collecting dates and production per quadrat of Montia fontana $\left(\mathrm{kg} / \mathrm{m}^{2}\right)$ at the two sites along the years of study

production per quadrat of Montia fontana at the two study sites along the years of study. As can be observed in the figure, the higher accumulated rainfall of Site 2 may explain the higher water-blink yield at this site in the two common sampled years. Likewise, the lower production in 2008 is surely due to the driest winter and spring of this year in both sites. The clear relation between water level and winter precipitation in Mediterranean streams is surely one of the major reasons for yield differences of this aquatic plant. These results completely agree with the popular perception about this plant which states that a rainy season (winter-spring) favours a great development of the plant whereas it hardly appears in dry periods (Díaz-Fernández et al. 2008).

No other reference about Montia fontana production has been found in the scientific literature. Therefore, we can only compare yield estimations of water-blinks with data from other species that often grows in the same habitat, such as watercress (Rorippa nasturtium-aquaticum). Following Guiberteau (1990), production of wild watercress can reach $2.5-4.5 \mathrm{~kg} / \mathrm{m}^{2}$, though this author does not mention the origin and measure conditions of these data. Assuming that these data were restricted to plant growing surface, the mean data obtained for waterblinks $\left(2.64 \mathrm{~kg} / \mathrm{m}^{2}\right.$, see Table $\left.2 \mathrm{~A}\right)$ are near of the lower extreme of the production range described for watercress. This was quite expectable considering the lower size of this plant.

There are, however, many references about watercress cultivation including some yield data (e.g. Fennell 2006; Guiberteau 1990; Schippers 2004) that could be useful for knowing the potential of waterblinks culture. Fennel (2006) documented a yield range of 7,500-10,000 kg/ha in UK, harvested about 6 times each year, and an average yield of $25,620 \mathrm{~kg} /$ ha in Hawaii, with the best growth occurring during the cool, wet season from October to April. Other authors mentioned even higher yield values of up to $50,000 \mathrm{~kg} / \mathrm{ha}$ (Schippers 2004). 
Watercress have been also extensively cultivated hydroponically in New Zealand, i.e., growing plants in water without soil using mineral nutrient solutions (Fennell 2006). There is also the chance of combining hydroponics and aquaculture in an established methodology referred to as aquaponics, a symbiotic system in which nitrogen waste from fish metabolites provides needed nutrients to the vegetable crop. The use of watercress in an aquaponic production system utilizing brook trout aquaculture effluent has been successfully proved in the US (Smith 2007). In our opinion, all these methods might also be adapted and employed with water-blinks. In fact, some hydroponic experiences have been done with the related species Portulaca oleracea L. (Fontana et al. 2006; Palaniswamy et al. 2002).

Nutritional value

Table 3 shows the proximate composition, mineral elements, vitamin $\mathrm{C}$ and organic acids levels found in the edible parts of Montia fontana. As can be seen in this table, wide variations were found among some measured parameters between years and sites. These variations are probably due to environmental factors and justify the importance of studying to what extent micronutrient contents of wild vegetable species varies according to geographical location, agricultural practices and climate, as stated by Flyman and Afolayan (2006).

Moisture was very stable among sites and years, and can be included within the range of most wild vegetables (Guil-Guerrero et al. 1997). Comparing with data of Souci et al. (2008), the mean moisture value obtained for Montia fontana (89.6\%) was higher than that of Urtica dioica L. (83.3\%) but lower than that of Cichorium intybus L. (94.1\%). These values were also similar to those described of Claytonia perfoliata $(92.4 \%$, Schelstraete and Kennedy 1980). The fact that Montia fontana lives in very wet habitats, does not seem to have an influence in a higher internal water content of the plant.

Protein content $(1.76 \%)$ was also a rather stable parameter and, following Souci et al. (2008), comparable to data of other wild leafy vegetables, of the same family as Portulaca oleracea (1.48\%, cited as $P$. sativa Haw.) or of other families, such as Cichorium intybus (1.22\%) and Valerianella locusta (L.) Laterr. (1.84\%, cited as V. olitoria (L.) Pollich).
Montia fontana stood out for its lipid content $(1.94 \%)$, higher than other vegetables mentioned in Souci et al. (2008), such as Rorippa nasturtiumaquaticum (cited as Nasturtium officinale $\mathrm{R}$. Br.) or Valerianella locusta $(0.3 \%$ and $0.36 \%$ respectively). This is one of the highest fat content values reported for wild or cultivated leafy vegetables, over the contents of Silene vulgaris (Moench) Garcke, Sonchus oleraceus L., Bryonia dioica Jacq., Chondrilla juncea L. and Lepidium sativum L. in a range of 1.2-1.5\% (Morales et al. 2011b; Souci et al. 2008). As far as we know, a higher value for lipid content has only been found in water spinach (Ipomoea aquatica Forssk.), a semi-aquatic plant native to tropics and subtropics that it is used as a leaf vegetable, being also cultivated in Southeast Asia, India and Southern China (Umar et al. 2007). These authors provided a lipid content value for this species of $11 \%$ in dry weight $(72.83 \%$ of moisture), equivalent to $2.99 \%$ in fresh weight. Nevertheless, if considering dry weight, the mean lipid content of Montia fontana $(17.51 \mathrm{~g} / 100 \mathrm{~g} \mathrm{dw})$ is even higher.

Lipid content may be the main responsible for the higher energy value of this species $(31.48 \mathrm{kcal} /$ $100 \mathrm{~g}$ ), higher than the values reported by Schelstraete and Kennedy (1980) for the close related species Claytonia perfoliata $(20 \mathrm{kcal} / 100 \mathrm{~g})$ but similar to other vegetables such as Cichorium endivia L. (escarole), with $30 \mathrm{kcal} / 100 \mathrm{~g}$. Together with moisture, energy value was one of the most stable parameters, with no statistically significant differences among years and locations.

However, available carbohydrates fluctuated significantly among the different analysed samples, ranging from 0.45 to $3.8 \%$. The global average value $(1.81 \mathrm{~g} / 100 \mathrm{~g})$ was higher than $0.59 \%$ described for Portulaca oleracea (Souci et al. 2008) but lower than $3.22 \%$ reported for Claytonia perfoliata (Schelstraete and Kennedy 1980).

After moisture, the major constituent was fibre (4.44\%), much higher than many salad vegetables, such as lettuce and watercress (around 1.4\% both). This content, that was also quite stable among sites and years, means that $100 \mathrm{~g}$ of water-blinks would provide about $25 \%$ of the requirements of fibre for adults published by the Food and Nutrition Board (Trumbo et al. 2002). The ratio between fibre content and available carbohydrates was 2.4 as an average, as it is usual in many vegetables. This is also very 


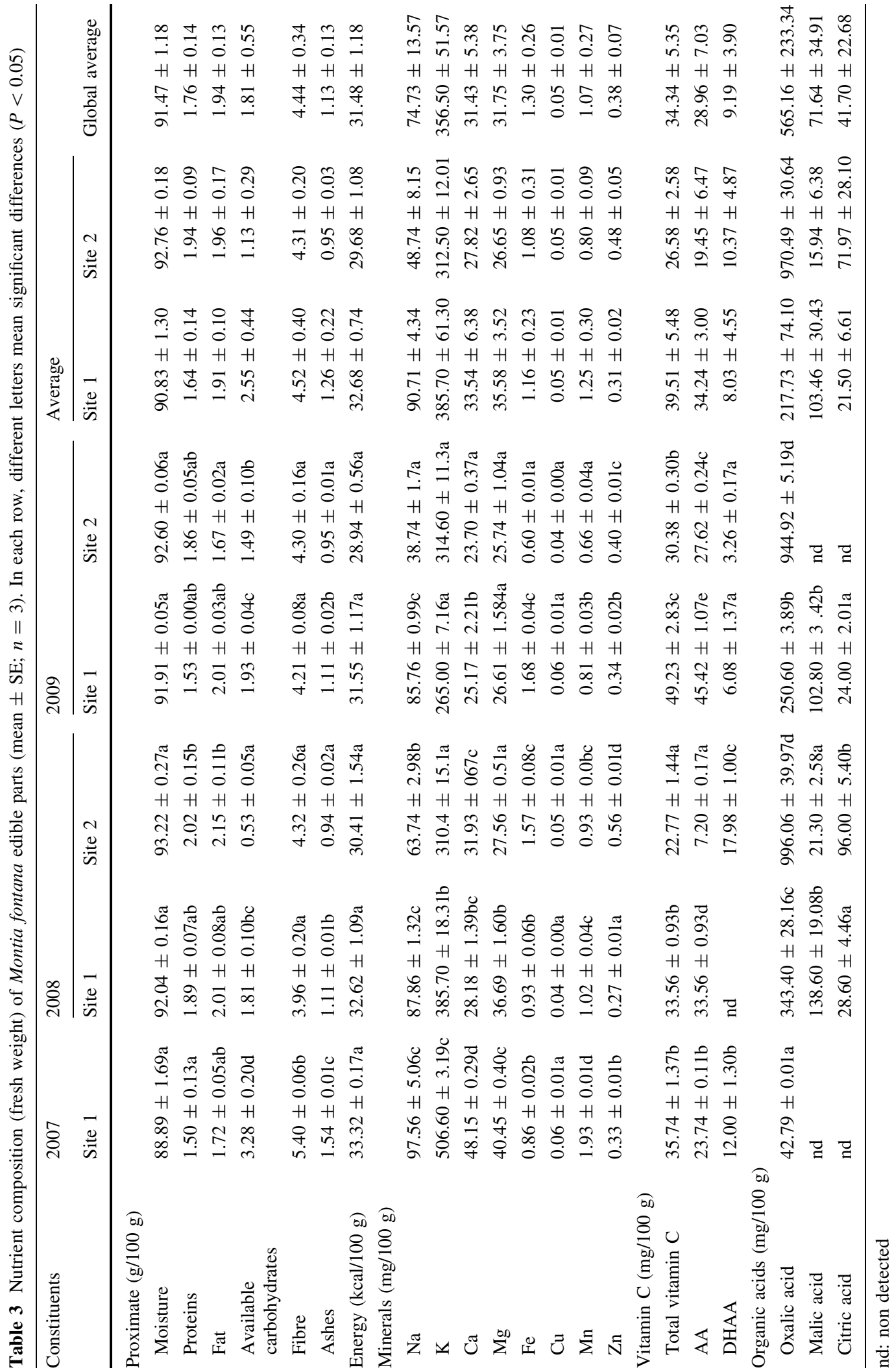


interesting from a nutritional point of view, being one of the reasons why increasing the intake of plant foods is highly recommended to improve human health.

Regarding mineral elements contents, high variations among years and locations were found, except for copper levels. Mineral content may be influenced by environmental conditions, as soil composition and, in the case of aquatic species, by water composition and volume of the streams where the plant lives. Despite the found variability, potassium was in higher levels than sodium (356 and $23 \mathrm{mg} / 100 \mathrm{~g}$ respectively), as it is common in plant foods. Montia fontana should be stood out by its content of manganese, reaching an average value of $1 \mathrm{mg} /$ $100 \mathrm{~g}$, while most of the vegetables are usually in the range of $0.07-0.4 \mathrm{mg} / 100 \mathrm{~g}$. There are only some exceptions as spinach (Spinacia oleracea L.) with $0.76 \mathrm{mg} / 100 \mathrm{~g}$ or the very high values of parsley (Petroselinum crispum [Mill.] Fuss) approaching to $3 \mathrm{mg} / 100 \mathrm{~g}$.

As expected, AA and DHA, being highly soluble and labile compounds, were quite influenced by the different environmental conditions where the plants were developed. However, despite the high variability found in our samples, Montia fontana could be considered as an interesting source of vitamin $\mathrm{C}$, with a total average content of $34.34 \mathrm{mg} / 100 \mathrm{~g}$. Moreover, taking into account that it is always consumed raw, there are no losses of this hydrosoluble vitamin due to cooking process. Comparing with other salad vegetables (Souci et al. 2008), its vitamin C content was higher than lettuce $(13 \mathrm{mg} / 100 \mathrm{~g})$ but lower than watercress $(96 \mathrm{mg} / 100 \mathrm{~g})$, being similar to lamb's lettuce $(35 \mathrm{mg} / 100 \mathrm{~g}$, Valerianella locusta) which is widely consumed nowadays in Europe. According to the Food and Nutrition Board (Trumbo et al., 2002), a portion of $100 \mathrm{~g}$ of Montia fontana would provide one-third of the Recommended Daily Allowances (RDA) for male adults (90 mg/day). As can be seen in Table 3, the predominant form of vitamin $\mathrm{C}$ was the reduced form, ascorbic acid (AA), contributing to about $2 / 3$ of total vitamin $\mathrm{C}$ activity. This form should be preferable, due to its antioxidant properties and higher stability in biological tissues (Schaffer et al. 2005; Vardavas et al. 2006).

Regarding organic acids, some plant species have a specific profile. In the case of Montia fontana, oxalic acid was always the major acid (see Fig. 3), while malic and citric acids were in variable contents.

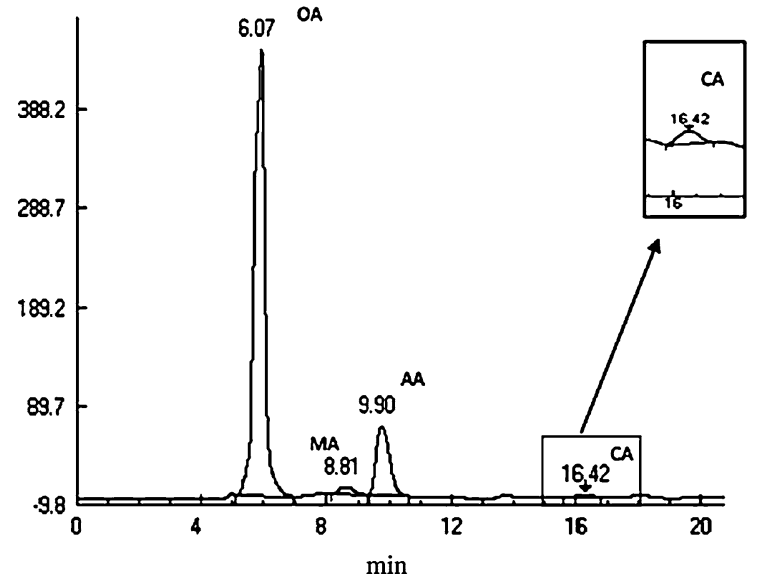

Fig. 3 HPLC profile of organic acids, including ascorbic acid, in Montia fontana (harvested in 2009, site 1). Chromatographic conditions: Sphereclone $\operatorname{ODS}(2),(250 \times 4.60 \mathrm{~mm}), 5 \mu \mathrm{m}$ column; mobile phase $1.8 \mathrm{mM} \mathrm{H} \mathrm{H}_{2} \mathrm{SO}_{4}(\mathrm{pH}=2.6)$; detection $=215 \mathrm{~nm}$; flow rate $=0.4 \mathrm{~mL} / \mathrm{min}$ : $O A$ oxalic acid, $M A$ malic acid, $A A$ ascorbic acid, $C A$ citric acid

Succinic and fumaric acid were found in some of the analysed samples in trace levels. However, as can be seen in Table 3, a high variability was found in these parameters among sites and years. The samples from Site 1 had a lower organic acid content than the samples from Site 2, especially the sample of 2007.

Average content of oxalic acid in Montia fontana (565 mg/100 g) was similar to that found in Silybum marianum (L.) Gaertn. and Beta maritima L., in a previous study of our group (Sánchez-Mata et al. 2011). However, a wide variation appears among the different samples harvested. The oxalic acid content of the plants gathered at Site 2 was especially high, near $1 \mathrm{~g} / 100 \mathrm{~g}$ in both samples. These values were even higher than the values reported by Guil et al. (1997) for Spanish wild Portulaca oleracea (0.77 g/ $100 \mathrm{~g}$ ) but lower or in the range of other oxalates-rich plants from the genera Amaranthus, Digera, Chenopodium, Beta or Euphorbia, which may reach values of $1.4 \mathrm{~g} / 100 \mathrm{~g}$ (Chai and Liebman 2005; Guil-Guerrero et al. 1997; Gupta et al. 2005; Uusiku et al. 2010). However, the oxalic acid content of the plants gathered at Site 1, though subjected to wider variability, was always under $350 \mathrm{mg} / 100 \mathrm{~g}$. Therefore, according our results, it seems that water-blinks collected at the highland streams have higher oxalic acid content than those from the lowlands.

Following Massey (2007), there are at least three different biological causes of variation in oxalate 
content between different samples: the plant part, genetic differences between cultivars, and cultivation conditions. In our case, the reasons for the differences found may be due both to genetic differences between the two selected plant populations and to differences in the environmental conditions, such as soil and water characteristics, of the two sites. Some authors (Fontana et al. 2006; Palaniswamy et al. 2002) have found that the oxalic acid content of the edible parts of Portulaca oleracea (hydroponically cultivated) was related to total nitrogen concentration and the ratio nitrate/ammonium of the nutritive solution. Increasing the total nitrogen concentration and lowering the ratio nitrate/ammonium of the nutritive solution lowered oxalic acid production in the plant. Although an in depth study is needed, at least a part of the significant differences in oxalic acid content found in our study might be also due to differences in the nitrogen content of soil or water of the streams where they were collected. However, as stated by Massey (2007), the differences in oxalate content of the final food due to grown conditions are usually quite modest compared to that due to the genetic differences.

Oxalate in plant tissues is presented as a combination of soluble oxalate sources such as sodium and potassium oxalate as well as insoluble oxalate salts such as calcium and magnesium oxalate (Chai and Liebman 2005). Members of more than 215 plant families accumulate crystals of calcium oxalate within their tissues, which include many crop plants, accumulating oxalate in the range of $3-80 \%$ of dry weight (Nakata 2003).

It is well known that the presence of oxalates in food plants can interfere with the absorption of calcium and contribute to the formation of oxalate kidney calculus, especially in certain individuals. However, according to Massey (2007), the amount of oxalate absorbed from a food is influenced by three major factors: the amount and form of oxalate in the food consumed, the amount of calcium and magnesium in the oxalate-containing food and/or meal, and the presence or absence of oxalate-degrading bacteria in the gut. Following Naudé and Naidoo (2007) in all cases of oxalate toxicity, animals or humans have to be rather abruptly exposed to large quantities of oxalate-containing plants these often being the only, or largely, the plants eaten. In this way, although the occasional consumption of Montia fontana in habitual amounts (100 g or less), would not reach the toxic doses of $5 \mathrm{~g}$ (Concon 1988), people more susceptible of suffering of kidney pathologies should moderate its intake as well as other oxalic-rich plants. As far as we know, no intoxication case has been described for the consumption of this plant.

Other interesting nutritional parameters, such as fatty acids and tocopherols, as well as antioxidant activity of Montia fontana have been previously studied by members of our research group (Morales et al. 2011a and 2011b). These studies reported a high percentage of polyunsaturated fatty acids $(67 \%)$, standing out for its high content (almost 50\%) in $\alpha$ linolenic acid (C18:3n3). This is a similar proportion than that reported for the close related species Portulaca oleracea, which has been considered by Simopoulos (2004), as one of the richest source of omega-3 fatty acids among the leafy vegetables. Bearing in mind the higher lipid content of Montia fontana $(1.94 \mathrm{~g} / 100 \mathrm{~g})$, this wild vegetable could be regarded as an even better source of this essential omega-3 fatty acid, with its known beneficial health effects (Simopoulos 2003, 2004). The other aforementioned work (Morales et al. 2011a) has reported that Montia fontana showed a high vitamin E activity (total tocopherols content of $8.03 \mathrm{mg} / 100 \mathrm{~g}$ dry weight), including a high $\alpha$-tocopherol content $(6.01 \mathrm{mg} / 100 \mathrm{~g}$ dry weight) as well as a good antioxidant activity compared with other wild vegetables.

\section{Conclusions}

As far as we know, this is the first report, both on natural production and nutritional composition, of Montia fontana, an interesting wild vegetable, widely appreciated and still consumed in many Spanish and Portuguese regions.

Quantitative data on water-blinks yield can be very useful in order to assess the availability and sustainability of this wild resource to local people in the regions where it grows. Our results showed that the harvest potential of the species strongly depends on the winter and spring rainfall. Likewise, production rates from wild populations are interesting to assess its agronomic potential. In our opinion, water-blinks could be cultivated in the same way as watercress, both in prepared beds fed by clean and running water 
or in a hydroponic system, and sold fresh in markets as other salad vegetables.

Regarding nutritional data, an important seasonal and environmental variability has been found, especially in mineral elements and available carbohydrates, which confirms the importance of studying samples collected in different moments and sites. Nevertheless, it can be concluded that Montia fontana is characterised by its high fibre, and manganese content, as well as the relatively high fat and vitamin $\mathrm{C}$ levels. It is also remarkable its high lipid content and therefore this wild vegetable could be regarded as one of the richest source of omega- 3 fatty acids among the leafy vegetables. The presence of high oxalic acid levels would not be an inconvenient in the habitual amounts traditionally consumed, although people more susceptible of suffering of kidney pathologies should moderate the intake of this species.

The high nutritional quality and bioactive compounds found in this species can be some of the unconscious reasons that explain its traditional and present consumption. Its vitamin $\mathrm{C}$ content might have been crucial in the nutrition of populations dependent on local resources, since this vegetable is available in late winter and early spring, when there were no many food sources of this vitamin in the diet.

Taking into account all these features, Montia fontana can be considered an interesting wild resource for being included in the diet. More research is needed about its potential for being cultivated under different culture systems and for selecting cultivars with lower oxalate content.

Acknowledgments Research funding was obtained from ERDF and the Spanish Ministry of Education and Science (CGL200609546/BOS). María Molina and Patricia García-Herrera were granted by predoctoral fellowships provided by IMIDRA and Universidad Complutense de Madrid, respectively. We want to thank to Susana González for collaborating in the field work and to Carmen Diez Marqués, for her support in mineral elements analysis.

\section{References}

Aceituno-Mata L (2010) Estudio etnobotánico y agroecológico de la Sierra Norte de Madrid. PhD thesis. Universidad Autónoma de Madrid. Available at http://digitool-uam. greendata.es

ADISAC (2006) Los guardianes de las semillas. ADISAC-La Voz, Zamora
Allen DE, Hatfield G (2004) Medicinal plants in folk tradition. An Ethnobotany of Britain \& Ireland. Timber Press, Cambridge

Alves Ribeiro J, Monteiro AM, Fonseca da Silva ML (2000) Etnobotânica. In: Joâo Azevedo (ed) Plantas bravias, comestíveis, condimentares e medicinais. Mirandela

AOAC (2006) Official methods of analysis, 18th edn. AOAC International, Arlington Virginia

Blanco E (1998) Diccionario de etnobotánica segoviana. Ayuntamiento de Segovia, Segovia

Blanco E, Cuadrado C (2000) Etnobotánica en Extremadura. Estudio de La Calabria y La Siberia extremeñas. Emilio Blanco y CEP Alcoba de los Montes, Madrid

Carvalho AM (2010) Plantas y sabiduría popular del Parque Natural de Montesinho. Un estudio etnobotánico en Portugal. CSIC, Madrid

Chai W, Liebman M (2005) Effect of different cooking methods on vegetable oxalate content. J Agric Food Chem 53:3027-3030

Concon JM (1988) Toxicology: principles and concepts. Marcel Dekker, New York

Couplan F (1989) Le regal vegetal. Plantes sauvages comestibles. Encyclopedie des plantes comestibles de l'Europe, vol 1. Equilibres Aujourd'houi, Flers

Criado J, Fernández López JM, Leocadio G, Núñez RM, Blanco E (2008) Uso tradicional de las plantas en Toledo. Diputación de Toledo, Toledo

Díaz-Fernández PM, Ramos Miras JJ, San José A, Pascual Gallego V, López-Almansa JC, Muñoz-Gallego CL (2008) Puesta en valor de recursos genéticos vegetales y su aplicación a estrategias de desarrollo rural. Estudio etnobotánico de Montia fontana $\mathrm{L}$. en la provincia de Ávila. CONAMA 9. Congreso Nacional de Medio Ambiente

EFSA Panel on Dietetic Products, Nutrition, Allergies (2010) Scientific opinion on dietary reference values for carbohydrates and dietary fibre. EFSA J 8(3):1462

Fennell JFM (2006) Potential for watercress production in Australia. Rural Industries Research and Development Corporation, Kingston ACT, Australia

Flyman MV, Afolayan AJ (2006) The sustainability of wild vegetables for alleviating human dietary deficiencies. S Afr J Bot 72:492-497

Fontana E, Hoeberechts J, Nicola S, Cros V, Palmegiano GB, Peiretti PG (2006) Nitrogen concentration and nitrate/ ammonium ratio affect yield and change the oxalic acid concentration and fatty acid profile of purslane (Portulaca oleracea L.) grown in a soilless culture system. J Sci Food Agric 86(14):2417-2424

González JA, García-Barriuso M, Amich F (2010) The consumption of wild and semi-domesticated edible plants in the Arribes del Duero (Salamanca-Zamora, Spain): an analysis of traditional knowledge. Genet Resour Crop Evol doi:10.1007/s10722-010-9635-8

Grivetti LE, Ogle BM (2000) Value of traditional foods in meeting macro- and micronutrient needs: the wild plant connection. Nutr Res Rev 13:31-46

Guiberteau A (1990) El berro: características y cultivo. Junta de Extremadura, Mérida

Guil-Guerrero JL, Rodríguez-Garcia I, Torija-Isasa ME (1997) Nutritional and toxic factors in selected wild edible plants. Plant Foods Hum Nutr 51(2):99-107 
Gupta S, Lakshmi AJ, Manjunath MN, Prakash J (2005) Analysis of nutrient and antinutrient content of underutilized green leafy vegetables. Lwt-Food Sci Technol 38(4):339-345

Hammer K (2001) Portulacaceae. In: Hanelt P, Institute of Plant Genetics and Crop Plant Research (eds) Mansfeld's encyclopedia of agricultural and horticultural crops. SpringerVerlag, Berlin, Heidelberg, New York., pp 223-227

Jage H (1979) Portulacaceae. In: Conert HJ, Schultze-Motel W, Wagenitz G (eds) Gustav Hegi Illustrierte Flora von Mitteleuropa. Paul Parey, Berlin-Hamburg, pp 1183-1221

Kerns BK, Alexander SJ, Bailey JD (2004) Huckleberry abundance, stand conditions, and use in Western Oregon: evaluating the role of forest management. Econ Bot 58(4):668-678

Lasheras C, Fernandez S, Patterson AM (2000) Mediterranean diet and age with respect to overall survival in institutionalized, nonsmoking elderly people. Am J Clin Nut 71(4):987-992

López-Bucio J, Nieto-Jacobo MF, Ramírez-Rodríguez V, Herrera-Estrella L (2000) Organic acid metabolism in plants: from adaptive physiology to transgenic varieties for cultivation in extreme soils. Plant Sci 160:1-13

Massey LK (2007) Food oxalate: factors affecting measurement, biological variation, and bioavailability. J Am Diet Assoc 107(7):1191-1194

McDermott JH (2000) Antioxidant nutrients: current dietary recommendations and research update. J A Pharm Assoc 40(6):785-799

Miinaa J, Pukkalab T, Hotanena JP, Saloa K (2010) Optimizing the joint production of timber and bilberries. Forest Ecol Manag 259:2065-2071

Moerman DE (1998) Native American Ethnobotany. Timber Press, Portland and Cambrige

Molina M, Pardo-de-Santayana M, Aceituno L, Morales R, Tardío J (2011) Fruit production of Strawberry-tree (Arbutus unedo L.) in two Spanish forests. Forestry doi: 10.1093/forestry/cpr031

Morales P, Carvalho AM, Sánchez-Mata MC, Cámara M, Molina M, Ferreira ICFR (2011a) Tocopherol composition and antioxidant activity of Spanish wild vegetables. Genet Resour Crop Evol doi:10.1007/s10722-011-9726-1

Morales P, Ferreira ICFR, Carvalho AM, Sánchez-Mata MC, Cámara M, Tardío J (2011b) Fatty acids characterization of twenty Spanish wild vegetables. Food Sci Technol Int (In Press)

Munro DB, Small E (1997) Vegetables of Canada. National Research Council of Canada, Ottawa

Murray G, Boxall PC, Wein RW (2005) Distribution, abundance, and utilization of wild berries by the Gwich'in people in the Mackenzie River Delta Region. Econ Bot 59(2): 174-184

Nakata PA (2003) Advances in our understanding of calcium oxalate crystal formation and function in plants. Plant Sci 164(6):901-909

Naudé TW, Naidoo V (2007) Oxalates-containing plants. In: Gupta RC (ed) Veterinary toxicology. Academic Press, New York, pp 880-891

Ogle BM (2001) Wild vegetables and micronutrient nutrition. studies on the significance of wild vegetables in women's diets in Vietnam. PhD thesis. Uppsala University, Uppsala
Oliveira AP, Pereira JA, Andrade PB, Valentão P, Seabra RM, Silva BM (2008) Organic acids composition of Cydonia oblonga Miller leaf. Food Chem 111:393-399

Osborne DR, Voogt P (1986) Análisis de los nutrientes de los alimentos. Ed. Acribia, S.A, Zaragoza

Paiva J, Villanueva E (1990) Montia L. In: Castroviejo S, Laínz M, López González G, Montserrat P, Muñoz Garmendia F, Paiva J, Villar L (eds) Flora Iberica, vol 1. CSIC, Madrid, pp 469-473

Paiva J, Cirujano S, Villanueva E (1986) Montia fontana L. (Portulacaceae) en la Península Ibérica. Bol Soc Brot, Sér 2, 59:321-333

Palaniswamy UR, Bible BB, McAvoy RJ (2002) Effect of nitrate:ammonium nitrogen ratio on oxalate levels of purslane. In: Janick J, Whipkey A (eds) Trends in new crops and new uses. ASHS Press, Alexandria, pp 453-455

Pardo de Santayana M, Tardío J, Blanco E, Carvalho AM, Lastra JJ, San Miguel E, Morales R (2007) Traditional knowledge on wild edible plants in the northwest of the Iberian Peninsula (Spain and Portugal): a comparative study. J Ethnobiol Ethnomed 3:27

PFAF (2011) Plants for a Future: edible, medicinal and useful plants for a healthier world. Database, available at http://www.pfaf.org. (Last accessed 13 April 2011)

Phillips KM, Tarragó-Trani MT, Gebhardt SE, Exler J, Patterson KY, Haytowitz DB, Pehrsson PR, Holden JM (2010) Stability of vitamin $C$ in frozen raw fruit and vegetable homogenates. J Food Compos Anal 23:253-259

Sánchez-Mata MC, Cabrera-Loera RD, Morales P, FernándezRuiz V, Cámara M, Díez-Marqués C, Pardo-de-Santayana M, Tardío J (2011) Wild vegetables of the Mediterranean area as valuable sources of bioactive compounds. Genet Resour Crop Evol doi:10.1007/s10722-011-9693-6

Sánchez-Monge E (2001) Diccionario de plantas de interés agrícola. Ministerio de Agricultura, Pesca y Alimentación, Madrid

Schaffer S, Schmitt-Schillig S, Müller WE, Eckert GP (2005) Antioxidant properties of mediterranean food plants extracts: geographical differences. J Physiol Pharmacol 56(Suppl. 1):115-124

Schelstraete M, Kennedy BM (1980) Composition of miner's lettuce (Montia perfoliata). J Am Diet Assoc 77(1):21-25

Schippers RR (2004) Nasturtium officinale. In: Grubben GJH, Denton OA (eds) Plant resources of tropical Africa 2. Vegetables. Prota Foundation-Backhuys Publishers-CTA, Wageningem, pp 401-403

Simopoulos AP (2003) Importance of the ratio of omega-6/ omega-3 essential fatty-acids: evolutionary aspects. In: Simopoulos AP, Cleland LG (eds) Omega-6/omega-3 essential fatty-acids: the scientific evidence. Karger, Basel, pp 1-22

Simopoulos AP (2004) Omega-3 fatty acids and antioxidants in edible wild plants. Biol Res 37:263-277

Smith EN (2007) Watercress (Nasturtium officinale) production utilizing brook trout (Salvelinus fontinalis) flowthrough aquaculture effluent. Davis College of Agriculture, Forestry, and Consumer Sciences at West Virginia University

Souci SW, Fachmann W, Kraut H (2008) Food composition and nutrition tables. Medpharm Scientific Publishers, Stuttgart 
Tardío J, Pascual H, Morales R (2002) Alimentos silvestres de Madrid. Guía de plantas y setas de uso alimentario tradicional en la Comunidad de Madrid. Ediciones La Librería, Madrid

Tardío J, Pascual H, Morales R (2005) Wild food plants traditionally used in the province of Madrid. Econ Bot 59(2):122-136

Tardío J, Pardo de Santayana M, Morales R (2006) Ethnobotanical review of wild edible plants in Spain. Bot J Linn Soc 152(1):27-72

Trumbo P, Schlicker S, Yates AA, Poos M (2002) Dietary reference intakes for energy, carbohydrate, fiber, fat, fatty acids, cholesterol, protein and amino acids. J Am Diet Assoc 102:1621-1630

Umar KJ, Hassan LG, Dangoggo SM, Ladan MJ (2007) Nutritional composition of water spinach (Ipomoea aquatica Forsk.) leaves. J Appl Sci 7(6):803-809
Uusiku NP, Oelofse A, Duodu KG, Bester MJ, Faber M (2010) Nutritional value of leafy vegetables of sub-Saharan Africa and their potential contribution to human health: a review. J Food Compos Anal 23(6):499-509

Vardavas CI, Majchrzak D, Wagner KH, Elmadfa I, Katafos A (2006) The antioxidant and phylloquinone content of wildly grown greens in Crete. Food Chem 99(4):813-821

Velasco JM, Criado J, Blanco E (2010) Usos tradicionales de las plantas en la provincia de Salamanca. Diputación de Salamanca, Salamanca

Walters SM (1964) Montia L. In: Tutin TG, Heywood VH, Burges DM, Moore DH, Valentine SM, Walters SM, Webb DA (eds) Flora Europaea, vol 1. The University Press, Cambridge and London, pp 114-115

Youngblood D (2004) Identification and quantification of edible plant foods in the upper (Nama) Karoo, South Africa. Econ Bot 58:43-65 